University of Nebraska - Lincoln

DigitalCommons@University of Nebraska - Lincoln

Faculty Papers and Publications in Animal

Science

Animal Science Department

January 2001

\title{
Candidate gene analysis for loci affecting litter size and ovulation rate in swine
}

R. C. Linville

University of Nebraska-Lincoln

Daniel Pomp

University of Nebraska-Lincoln, dpomp1@unl.edu

R. K. Johnson

University of Nebraska-Lincoln, rjohnson5@unl.edu

M. F. Rothschild

lowa State University

Follow this and additional works at: https://digitalcommons.unl.edu/animalscifacpub

Part of the Animal Sciences Commons

Linville, R. C.; Pomp, Daniel; Johnson, R. K.; and Rothschild, M. F., "Candidate gene analysis for loci affecting litter size and ovulation rate in swine" (2001). Faculty Papers and Publications in Animal Science. 98.

https://digitalcommons.unl.edu/animalscifacpub/98

This Article is brought to you for free and open access by the Animal Science Department at DigitalCommons@University of Nebraska - Lincoln. It has been accepted for inclusion in Faculty Papers and Publications in Animal Science by an authorized administrator of DigitalCommons@University of Nebraska - Lincoln. 


\title{
Candidate gene analysis for loci affecting litter size and ovulation rate in swine $e^{1,2,3,4}$
}

\author{
R. C. Linville*,5, D. Pomp*, R. K. Johnson*,6, and M. F. Rothschild $\dagger$ \\ *Department of Animal Science, University of Nebraska, Lincoln 68583-0908 and \\ $\dagger$ Department of Animal Science, Iowa State University, Ames 50011-3150
}

\begin{abstract}
A candidate gene approach was used to determine whether specific loci explain responses in ovulation rate $(\mathrm{OR})$ and number of fully formed $(\mathrm{FF})$, live (NBA), stillborn, and mummified pigs at birth observed in two lines selected for ovulation rate and litter size compared with a randomly selected control line. Line IOL was selected for an index of OR and embryonic survival for eight generations, followed by eight generations of two-stage selection for OR and litter size. Line $\mathrm{C}$ was selected at random for 16 generations. Line COL, derived from line $\mathrm{C}$ at Generation 8, underwent eight generations of two-stage selection. Lines IOL and C differed in mean EBV by 6.1 ova and $4.7 \mathrm{FF}$, whereas lines COL and C differed by 2.2 ova and $2.9 \mathrm{FF}$. Pigs of Generation 7 of two-stage selection lines were genotyped for the retinol binding protein $4(R B P 4, \mathrm{n}=190)$ and epidermal growth factor $(E G F, \mathrm{n}=189)$ loci, whereas pigs of Generations 7 and 8 were genotyped for
\end{abstract}

the estrogen receptor ( $E S R, \mathrm{n}=523$ ), prolactin receptor $(P R L R, \mathrm{n}=524)$, follicle-stimulating hormone $\beta(F S H \beta$, $\mathrm{n}=520$ ), and prostaglandin-endoperoxide synthase 2 (PTGS2, $\mathrm{n}=523$ ) loci. Based on chi-square analysis for homogeneity of genotypic frequencies, distributions for $P R L R, F S H \beta$, and PTGS2 were different among lines $(P<0.005)$. Differences in gene frequencies between IOL vs $\mathrm{C}$ and COL vs $\mathrm{C}$ were $0.33 \pm 0.25$ and $0.16 \pm$ 0.26 for PRLR, $0.35 \pm 0.20$ and $0.15 \pm 0.24$ for $F S H \beta$, and $0.16 \pm 0.16$ and $0.08 \pm 0.18$ for PTGS2. Although these differences are consistent with a model of selection acting on these loci, estimates of additive and dominance effects at these loci did not differ from zero $(P>$ 0.05 ), and several of them had signs inconsistent with the changes in allele frequencies. We were not able to find significant associations between the polymorphic markers and phenotypes studied; however, we cannot rule out that other genetic variation within these candidate genes has an effect on the traits studied.

Key Words: Candidate Genes, Litter Size, Ovulation Rate, Pigs, Reproduction

(02001 American Society of Animal Science. All rights reserved.

J. Anim. Sci. 2001. 79:60-67

\section{Introduction}

Reproductive rate, especially litter size, is one of the most economically important traits in pig production.

\footnotetext{
${ }^{1}$ Published as Paper No. 12981 journal ser., Nebraska Agric. Res. Div.

${ }^{2}$ We acknowledge the contributions of Lori Messer for supervising laboratory procedures involved in DNA analyses and Joe Cassady for assistance in collection of phenotypic data.

${ }^{3}$ This research was partially funded by USDA National Research Initiative and Competitive Grant 96-35205-3437 and contributed to objectives of the NC 220 Regional Research and NRSP8 National Research Projects. Careful reading of the manuscript and comments by G. Rohrer, A. Clutter, and M. Soller are appreciated.

${ }^{4}$ Gene tests for $E S R, P R L R, R B P 4$, and $E G F$ are covered by existing patents and their commercial use is prohibited. This is Journal No. J-18768, Project No 3148 of the Iowa Agric. and Home Econ. Exp. Sta.

${ }^{5}$ Current address: 407 Wagon Wheel Ln., Louisburg, NC 27549.

${ }^{6}$ Correspondence: phone: 402-472-6404; fax: 402-472-6362; E-mail: rjohnson5@unl.edu.

Received April 19, 2000.

Accepted August 18, 2000.
}

Increasing the number of pigs weaned per sow will increase economic returns for pig producers with minimal additional inputs (Rothschild, 1996).

Currently, litter size varies from approximately 2 to 20 pigs per litter, with means from 9 to 11, depending on the breed. Phenotypic standard deviations are between 2.5 and 3 pigs, and heritability is 10 to $15 \%$ (Johnson et al., 1999). Therefore, sufficient genetic variability exists to increase litter size. However, litter size is sex-limited and selection response could be enhanced by direct selection in both sexes for genes affecting its expression.

Advances in molecular techniques can now be used to increase rate of response to selection. It has been proposed that candidate gene analyses be used to identify individual genes responsible for traits of economic importance (Rothschild and Soller, 1997). For example, Short et al. (1997) found the additive effect associated with the B allele of the estrogen receptor $(\boldsymbol{E S R})$ gene was 0.42 pigs per litter in first-parity gilts. The objective of this study was to determine whether certain candi- 
date genes explain responses in ovulation rate and litter size in two lines that were selected either 16 or 8 total generations for ovulation rate, embryonic survival, and litter size.

\section{Materials and Methods}

Population. The population of pigs sampled in this experiment was developed at the University of $\mathrm{Ne}$ braska Swine Research Station. Three lines that originated from the Index (I) and Control (C) lines described in Johnson et al. (1999) were used. The Index and Control lines had a common base of a Landrace/Large White composite population. Pigs were randomly assigned, within litter, to either line I or line $\mathrm{C}$ at Generation 0 and then selected for increased values of an index of ovulation rate and embryonic survival (Line I) or randomly (Line C). At Generation 8 of index selection, the lines reported on here and designated as IOL and COL were formed from line I and line C, respectively. Eight generations of two-stage selection in lines IOL and COL were practiced. Stage-one selection included all gilts from $50 \%$ of litters with the greatest number of fully formed pigs at birth. Stage-two selection included the $50 \%$ of these gilts with the greatest ovulation rate, measured by counting the number of corpora lutea via laporatomy at second estrus. Line $\mathrm{C}$ continued to be randomly selected.

At Generation 0 of two-stage selection, line I, and thus line IOL, differed from line C by 4.22 ova and 1.94 pigs (Ruiz-Flores et al., 1999). After eight generations of two-stage selection, lines IOL and C differed in mean estimated breeding value by 6.1 ova and 4.7 fully formed pigs, whereas lines COL and C differed by 2.24 ova and 2.9 fully formed pigs. The inbreeding coefficients were $0.191,0.141$, and 0.137 for lines IOL, COL, and $\mathrm{C}$, respectively, at Generation 8.

Measurement of Traits. Animal management and procedures to record traits are described in Johnson et al. (1999) and in Ruiz-Flores et al. (1999). All data are for first-parity females. Gilts were observed for estrus and date of final estrus was recorded. Laparotomy was performed between 8 and $14 \mathrm{~d}$ after gilts expressed their second estrus. Selected gilts were mated at their third or fourth estrus and numbers of fully formed, live, stillborn, and mummified pigs at birth were recorded. Data for this experiment are from pigs of Generations 7 and 8 of two-stage selection. Ovulation rate in 382 gilts and litter size data in 244 gilts were recorded.

DNA Preparation. Ear tissue of pigs in Generations 7 and 8 was collected. In Generation 7, only the selected gilts and boars that were mated were sampled $(\mathrm{n}=192)$. In Generation 8, tissue was collected from all gilts in which laporatomy was performed and in all breeding boars $(\mathrm{n}=332)$. Genomic DNA was purified by standard procedures using proteinase $\mathrm{K}$ digestion followed by phenol/chloroform extraction and precipitation with isopropanol.
Candidate Genes. Pigs were genotyped for six candidate genes (Table 1) chosen based on known physiological mechanisms or because the gene was found to be associated with litter size in other studies. Information for PCR-based genotyping for all gene markers is in Tables 1 and 2.

Primers and reaction conditions for estrogen receptor $(\boldsymbol{E S R})$ were those described in Short et al. (1997). The pig specific primers and reaction conditions for epidermal growth factor $(\boldsymbol{E} \boldsymbol{G F})$ are described in Mendez et al. (1999). Amplification of $E G F$ with the pig specific primers sometimes yielded ambiguous genotypes because the A allele in the heterozygote amplified inefficiently. A second primer pair was used to amplify only the A allele ( $E G F \mathrm{~L} 1 \mathrm{~F}$, Table 1$)$ to differentiate between the $\mathrm{AB}$ and $\mathrm{BB}$ genotypes. The same reaction conditions were used for both primer pairs.

Primers for the beta subunit of follicle-stimulating hormone $\beta(\boldsymbol{F S H} \beta)$ were developed from pig sequence data (Genbank accession no. D00621). Primers for prolactin receptor $(\boldsymbol{P R L R})$ were developed by M. F. Rothschild (unpublished data). The $\mathrm{AB}$ and $\mathrm{BB}$ genotypes for PRLR were distinguishable by the intensity of the 127-bp band (Table 1), which was much darker in the $\mathrm{AB}$ genotype. A monomorphic band of size $35 \mathrm{bp}$ comigrated with the 35-bp digestion product in the B allele.

Reaction conditions and primer sequences for prostaglandin-endoperoxide synthase 2 (PTGS2) are described in Gladney et al. (1999). Primers for retinolbinding protein 4 ( $\boldsymbol{R B P 4})$ were developed by Rothschild et al. (2000) and reaction conditions are in Messer et al. (1996b).

Statistical Analysis. Allele frequencies were determined by the total count of an allele in a line divided by twice the number of observations in that line. A chisquare analysis for homogeneity of genotypic frequencies across lines was conducted in a $3 \times 3$ contingency table (Weir, 1996). The null hypothesis was that genotypic frequencies across lines were homogeneous. If a significant chi-square was obtained from Generation 7 data, then pigs of Generation 8 were also genotyped for that locus. The genotypes determined for Generation 7 animals were for the boars and gilts selected as parents of Generation 8. Thus, if genotypic frequencies among lines did not differ for parents, then differences among their progeny were not expected. Generation 8 progeny were genotyped to increase sample size if genotypic frequencies differed among Generation 7 parents.

Changes in allele frequencies between lines IOL and $\mathrm{C}$ and between COL and $\mathrm{C}$ were determined by subtraction. A standard error for the difference in gene frequency was determined by a method described in Ollivier et al. (1997) that accounted for genetic drift. The formula was: $\mathrm{V}\left(\hat{\mathrm{p}}_{\mathrm{gs}}-\hat{\mathrm{p}}_{\mathrm{gc}}\right)=\hat{\mathrm{q}}_{\mathrm{gc}} \hat{\mathrm{p}}_{\mathrm{gc}}\left(1 /\left[2 \mathrm{n}_{\mathrm{gc}}\right]+\mathrm{F}_{\mathrm{gc}}\right)+\hat{\mathrm{q}}_{\mathrm{gs}} \hat{\mathrm{p}}_{\mathrm{gs}}(1 /$ $\left[2 \mathrm{n}_{\mathrm{gs}}\right]+\mathrm{F}_{\mathrm{gs}}$ ), where $\hat{\mathrm{p}}$ and $\hat{\mathrm{q}}$ are estimates of gene frequencies, the subscript $\mathrm{g}$ represents the seventh or eighth generation, the subscripts $\mathrm{c}$ and $\mathrm{s}$ code for either the control line or a selection line, respectively, $\mathrm{F}$ is the inbreeding coefficient in Generation $\mathrm{g}$, and $\mathrm{n}$ is the 
Table 1. Primer sequences, restriction enzymes, allele sizes, and chromosomal locations of candidate genes

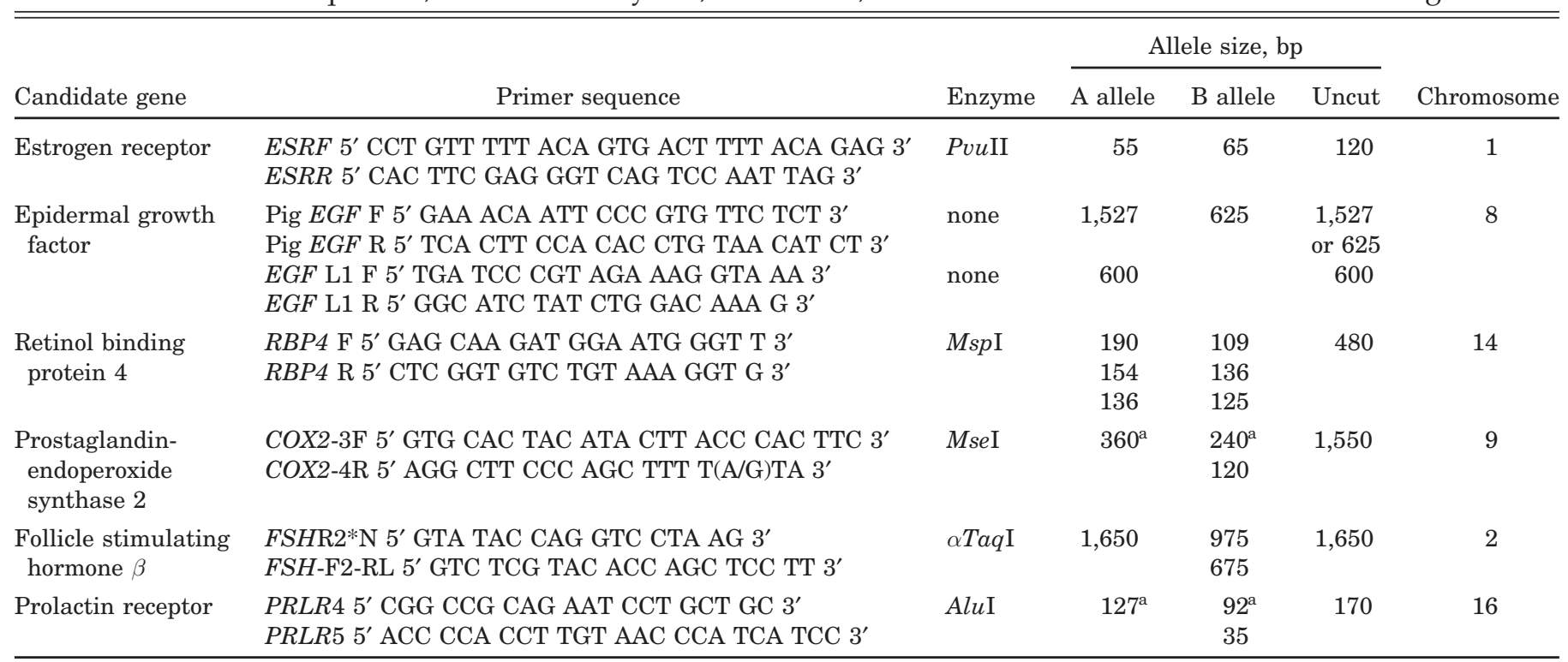

${ }^{\mathrm{a}}$ Monomorphic bands were also present.

number of animals with genotypic data per line. The line designated by s was either IOL or COL depending on the standard error being calculated (IOL-C or COL-C).

Data were analyzed using the MTDFREML program (Boldman et al., 1993) with an animal model including pedigree relationships back to the base generation of the population, year, and line as fixed effects. In one model, a covariate of the number of favorable alleles in the genotype for each gene $(0,1$, or 2$)$ was added to estimate the effects of allele substitution, and in a separate model, the effects of each genotype were estimated by fitting a fixed class variable with values of 0,1 , or 2 for the number of favorable alleles in the genotype. Only phenotypic data for Generations 7 and 8 were analyzed because genotypic data were available only for these generations. Therefore, line was included in the model to account for previous selection effects.

The genotypes of all six markers were fitted simultaneously. The favorable allele was defined as the one with increased frequency in the selection lines compared to the control line. Additive (a) and dominance (d) effects, as defined by Falconer and Mackay (1996), were estimated with orthogonal contrasts of solutions for genotypic effects. The mixed-model analysis was expected to produce unbiased estimates of a and d effects of the loci studied, averaged within line, independent of other polygenic effects on the traits (Kennedy et al., 1992).

The a and d effects of each allele also were estimated with PROC GLM of SAS (SAS Inst., Inc., Cary, NC) to determine whether solutions differed without correction for the effects of the other candidate genes and without correction for breeding values due to genes not included in the model. These analyses were performed fitting effects of each gene independently. The model included fixed effects of year and line and the appropriate genotypic classes as fixed effects.

\section{Results}

Allele frequencies are presented in Table 3. As expected for Type I markers, only two alleles for each marker existed. Both alleles for each marker were present in all three lines, although sometimes at low frequency, except for the B allele of ESR, which did not exist in the sample of animals of the COL and C lines. The A allele was designated as favorable for PTGS2

Table 2. PCR reaction conditions for the candidate genes ${ }^{a}$

\begin{tabular}{|c|c|c|c|c|c|c|}
\hline Candidate gene & $\begin{array}{c}\mathrm{dNTP}, \\
\mu M \text { each }\end{array}$ & $\begin{array}{l}\text { Primer, } \\
\mathrm{n} M \text { each }\end{array}$ & $\begin{array}{l}\mathrm{MgCl}_{2} \\
\mathrm{~m} M\end{array}$ & $\begin{array}{l}\text { Taq } \\
\text { units }\end{array}$ & $\begin{array}{c}\text { Reaction } \\
\text { volume, } \mu \mathrm{L}\end{array}$ & $\begin{array}{l}\text { Genomic } \\
\text { DNA, ng }\end{array}$ \\
\hline Estrogen receptor & 200 & 200 & 1.5 & 1.15 & 30 & 50 \\
\hline Retinol binding protein 4 & 100 & 320 & 1.5 & 1 & 20 & 50 \\
\hline Prostaglandin-endoperoxide synthase 2 & 200 & 250 & 1.5 & 0.5 & 10 & 50 \\
\hline Follicle-stimulating hormone $\beta$ & 100 & 200 & 1.5 & 1 & 20 & 50 \\
\hline
\end{tabular}

${ }^{a}$ All reactions used $1 \times$ concentration of the supplied PCR buffer and $1 \times$ RediLoad (Research Genetics, Huntsville, AL). 
Table 3. Allele frequencies overall and within lines IOL, COL, and $\mathrm{C}^{\mathrm{a}}$

\begin{tabular}{|c|c|c|c|c|c|}
\hline Candidate gene & Allele & Overall & IOL & $\mathrm{COL}$ & $\mathrm{C}$ \\
\hline \multirow{2}{*}{$\begin{array}{l}\text { Estrogen receptor } \\
(E S R, \mathrm{n}=520)\end{array}$} & $\mathrm{A}$ & 0.98 & 0.94 & 1 & 1 \\
\hline & B & 0.02 & 0.06 & 0 & 0 \\
\hline \multirow{2}{*}{$\begin{array}{l}\text { Epidermal growth factor } \\
(E G F, \mathrm{n}=190)\end{array}$} & $\mathrm{A}$ & 0.08 & 0.06 & 0.1 & 0.1 \\
\hline & B & 0.92 & 0.94 & 0.9 & 0.9 \\
\hline \multirow{2}{*}{$\begin{array}{l}\text { Retinol binding protein } 4 \\
(R B P 4, \mathrm{n}=190)\end{array}$} & $\mathrm{A}$ & 0.45 & 0.46 & 0.47 & 0.42 \\
\hline & B & 0.54 & 0.54 & 0.53 & 0.58 \\
\hline \multirow{2}{*}{$\begin{array}{l}\text { Prostaglandin-endoperoxide synthase } 2 \\
(P T G S 2, \mathrm{n}=523)\end{array}$} & $\mathrm{A}$ & 0.91 & 0.98 & 0.9 & 0.82 \\
\hline & B & 0.09 & 0.02 & 0.1 & 0.18 \\
\hline \multirow{2}{*}{$\begin{array}{l}\text { Follicle-stimulating hormone } \\
(\mathrm{FSH} \beta, \mathrm{n}=520)\end{array}$} & $\mathrm{A}$ & 0.2 & 0.03 & 0.23 & 0.38 \\
\hline & B & 0.8 & 0.97 & 0.77 & 0.62 \\
\hline \multirow{2}{*}{$\begin{array}{l}\text { Prolactin receptor } \\
(P R L R, \mathrm{n}=524)\end{array}$} & $\mathrm{A}$ & 0.33 & 0.19 & 0.36 & 0.42 \\
\hline & B & 0.67 & 0.81 & 0.64 & 0.58 \\
\hline
\end{tabular}

${ }^{\mathrm{a}}$ Lines IOL, COL and $\mathrm{C}$ are from the Nebraska selection lines. IOL was selected eight generations for index of ovulation rate and embryo survival, followed by eight generations of two-stage selection for ovulation rate and litter size. COL was selected at random for eight generations, followed by eight generations of two-stage selection. Line $\mathrm{C}$ was randomly selected for 16 generations.

and $R B P 4$, whereas $\mathrm{B}$ was designated as favorable for $E S R, F S H \beta, E G F$, and PRLR. There was an approximate linear increase in frequency of the favorable allele for $F S H \beta, P T G S 2$, and PRLR, genes for which the frequency of the favorable allele in line COL was intermediate to frequencies in lines $\mathrm{C}$ and IOL (Table 3).

Chi-square statistics for homogeneity of genotypic frequencies (Table 4) for FSH $\beta, P T G S 2, P R L R$, and $E S R$ were significant. It is likely that the chi-square statistic for $E S R$ is significant because there were several zeros in the observational cells of the contingency table. Small values (less than 5) in individual cells of the contingency table inflate the chi-square value (Weir, 1996). Thus, the chi-square test for the ESR locus is not accurate and we cannot conclude that genotypic frequencies differ across lines.

Changes in allele frequencies are presented in Table 5. After accounting for potential genetic drift, none of the differences in allele frequencies between selection lines and line $\mathrm{C}$ was significantly different from zero.

None of the estimates of the effects of allele substitution differed significantly from zero. These results are not presented because they can be calculated with formulas found in Falconer and Mackay (1996) using estimates of gene frequencies (Table 3 ) and a and d effects (Table 6).

Estimates of the additive and dominance effects of alleles calculated with an animal model are in Table 6 . Only the estimate of dominance effect of PTGS2 on number of mummies differed from zero. Estimates of a and $d$ effects calculated without an animal model (not shown) were very similar to those in Table 6 .

\section{Discussion}

Choice of Candidate Genes. The estrogen receptor locus was chosen because results from Rothschild et al. (1996) and Short et al. (1997), using data from nearly 10,000 litters from several lines, reported that the ESR $B$ allele was significantly associated with increased number of pigs per litter at birth. Estrogen is involved in maternal recognition of pregnancy (Geisert et al., 1990). It is produced by the growing conceptus and is

Table 4. Observed numbers of genotypes in lines IOL, $\mathrm{COL}$, and $\mathrm{C}$ and chi-square tests of homogeneity of genotypic frequencies ${ }^{\mathrm{a}}$

\begin{tabular}{|c|c|c|c|c|}
\hline Genotype & IOL & COL & $\mathrm{C}$ & $\chi^{2}$ \\
\hline & & $E S R$ & & \\
\hline $\mathrm{AA}$ & 166 & 198 & 136 & \\
\hline $\mathrm{AB}$ & 22 & 0 & 0 & \\
\hline \multirow[t]{2}{*}{$\mathrm{BB}$} & 1 & 0 & 0 & $42.5^{* * * *}$ \\
\hline & & $E G F$ & & \\
\hline $\mathrm{AA}$ & 0 & 0 & 0 & \\
\hline $\mathrm{AB}$ & 8 & 13 & 11 & \\
\hline \multirow[t]{2}{*}{$\mathrm{BB}$} & 58 & 55 & 45 & 2.7 \\
\hline & & $R B P 4$ & & \\
\hline $\mathrm{AA}$ & 8 & 15 & 12 & \\
\hline $\mathrm{AB}$ & 46 & 35 & 21 & \\
\hline \multirow[t]{2}{*}{$\mathrm{BB}$} & 13 & 19 & 21 & 12.3 \\
\hline & & PTGS2 & & \\
\hline $\mathrm{AA}$ & 181 & 162 & 94 & \\
\hline $\mathrm{AB}$ & 8 & 33 & 36 & \\
\hline \multirow[t]{2}{*}{$\mathrm{BB}$} & 0 & 2 & 7 & $47.2^{* * *}$ \\
\hline & & $F S H \beta$ & & \\
\hline $\mathrm{AA}$ & 0 & 8 & 16 & \\
\hline $\mathrm{AB}$ & 12 & 73 & 70 & \\
\hline \multirow[t]{2}{*}{$\mathrm{BB}$} & 176 & 115 & 50 & $124.7^{* * *}$ \\
\hline & & PRLR & & \\
\hline $\mathrm{AA}$ & 4 & 23 & 35 & \\
\hline $\mathrm{AB}$ & 64 & 97 & 73 & \\
\hline $\mathrm{BB}$ & 121 & 78 & 29 & $79.6^{* * *}$ \\
\hline
\end{tabular}

${ }^{\mathrm{a}} \mathrm{AA}, \mathrm{AB}$, and $\mathrm{BB}$ are the genotypes for the markers estrogen receptor $(E S R)$, epidermal growth factor $(E G F)$, retinol binding protein (RBP4), prostaglandin endoperoxide-synthase 2 (PTGS2), folliclestimulating hormone $(F S H \beta)$, and prolactin receptor $(P R L R)$. The expected values were calculated by dividing the total for a genotype by the grand total, then multiplying by the total for each line. IOL was selected eight generations for index followed by eight generations of two stage selection, COL was selected randomly for eight generations followed by eight generations of two-stage selection, and $\mathrm{C}$ was randomly selected for 16 generations.

$* * * P<0.001$. 
Table 5. Differences in allele frequencies of lines IOL and COL from $\mathrm{C}^{\mathrm{a}}$

\begin{tabular}{|c|c|c|c|c|c|c|}
\hline Candidate gene & IOL-C & $\begin{array}{c}\text { SE } \\
\text { w/drift }\end{array}$ & $\begin{array}{l}\text { SE } \\
\text { w/o } \\
\text { drift }\end{array}$ & COL-C & $\begin{array}{c}\text { SE } \\
\text { w/drift }\end{array}$ & $\begin{array}{c}\text { SE } \\
\text { w/o drift }\end{array}$ \\
\hline $\begin{array}{c}\text { Estrogen receptor } \\
(E S R, \mathrm{n}=520)\end{array}$ & 0.06 & 0.116 & 0.039 & 0 & 0.116 & 0.039 \\
\hline $\begin{array}{l}\text { Epidermal growth factor } \\
(E G F, \mathrm{n}=190)\end{array}$ & 0.04 & 0.156 & 0.035 & 0 & 0.156 & 0.038 \\
\hline $\begin{array}{l}\text { Retinol binding protein } 4 \\
(R B P 4, \mathrm{n}=190)\end{array}$ & 0.04 & 0.29 & 0.063 & 0.05 & 0.27 & 0.063 \\
\hline $\begin{array}{l}\text { Prostaglandin-endoperoxide } \\
\text { synthase } 2 \\
(P T G S 2, \mathrm{n}=523)\end{array}$ & 0.16 & 0.156 & 0.007 & 0.08 & 0.18 & 0.0005 \\
\hline $\begin{array}{l}\text { Follicle-stimulating hormone } \\
(F S H \beta, \mathrm{n}=520)\end{array}$ & 0.35 & 0.2 & 0.03 & 0.15 & 0.24 & 0.035 \\
\hline $\begin{array}{r}\text { Prolactin receptor } \\
(P R L R, \mathrm{n}=524)\end{array}$ & 0.33 & 0.25 & 0.038 & 0.16 & 0.26 & 0.038 \\
\hline
\end{tabular}

${ }^{\text {a}}$ IOL was selected eight generations for index of ovulation rate and embryonic survival, followed by eight generations of two-stage selection for ovulation rate and litter size. COL underwent two-stage selection for eight generations, subsequent to eight generations of random selection. Line $\mathrm{C}$ was randomly selected for 16 generations.

recognized by receptors in the uterus of the sow. Also, estrogen acts to induce hypertrophy and hyperplasia of the myometrial cells (Hafez, 1993).

Epidermal growth factor was chosen based on its role in the physiology of reproduction. Epidermal growth factor is produced by the conceptus and in the uterus of the sow. In the fetus, $E G F$ stimulates growth and proliferation of skin epithelia; in the neonate, $E G F$ stimulates pulmonary epithelia to grow and mature (Hadley, 1996).

Follicle-stimulating hormone is a heterodimer composed of alpha and beta subunits that are coded by two distinct genes. The beta subunit offers specificity. Follicle-stimulating hormone was chosen as a candidate gene because it functions in maturation of small and medium follicles into large follicles that ovulate (Wang and Greenwald, 1993a,b; Mannaertz et al., 1994). Also, in a candidate gene analysis, $\mathrm{Li}$ et al. (1998) found major effects on litter size associated with a marker within $F S H \beta$.

The prolactin receptor locus was chosen as a candidate gene because Vincent et al. (1998) reported that it was associated with litter size in three of the five lines of pigs they studied. Prolactin affects production of progesterone and relaxin from the corpora lutea, as determined by comparison of hypophysectomized gilts with and without prolactin treatment vs sham-operated gilts (Yangfan et al., 1989). It was inferred in that study that prolactin is leuteotropic during the latter part of pregnancy.

Prostaglandin-endoperoxide synthase 2, also known as cyclooxygenase 2 (COX2), was chosen because it is the rate-limiting enzyme in the formation of prostaglandins (Lim et al., 1997). A null mutation that produced

Table 6. Additive (a) effects of favorable ${ }^{\mathrm{a}}$ allele and dominance (d) effects estimated with an animal model ${ }^{\mathrm{b}, \mathrm{c}}$

\begin{tabular}{lcccccccccccc}
\hline \hline Candidate gene & Contrast & OR & SE & FF & SE & NBA & SE & Stillborn & SE & Mummies & SE \\
\hline \multirow{2}{*}{ ESR } & \multirow{2}{*}{ BB-AA } & a & 0.108 & 1.3 & 1.74 & 1.6 & 0.474 & 1.52 & 1.25 & 0.761 & 0.341 & 0.437 \\
& & $\mathrm{~d}$ & 2.33 & 1.42 & 2.72 & 1.98 & 1.58 & 1.88 & 1.13 & 0.933 & 0.37 & 0.54 \\
RBP4 & \multirow{2}{*}{ AA-BB } & $\mathrm{a}$ & -0.284 & 0.38 & 0.179 & 0.457 & 0.526 & 0.436 & -0.346 & 0.22 & -0.026 & 0.124 \\
& & $\mathrm{~d}$ & 0.315 & 0.49 & 0.441 & 0.627 & 0.313 & 0.595 & 0.0936 & 0.298 & -0.0479 & 0.17 \\
PTGS2 & AA-BB & $\mathrm{a}$ & 0.036 & 0.64 & 0.589 & 0.833 & 0.403 & 0.795 & 0.184 & 0.399 & 0.273 & 0.226 \\
& & $\mathrm{~d}$ & 0.448 & 0.71 & 0.354 & 0.953 & 0.076 & 0.909 & 0.278 & 0.454 & $0.741^{*}$ & 0.259 \\
FSH $\beta$ & \multirow{2}{*}{ BB-AA } & $\mathrm{a}$ & -0.04 & 0.34 & 0.163 & 0.466 & 0.12 & 0.446 & 0.045 & 0.223 & 0.246 & 0.127 \\
& & $\mathrm{~d}$ & -0.039 & 0.41 & 0.979 & 0.577 & 0.759 & 0.549 & 0.222 & 0.273 & 0.0481 & 0.157 \\
PRLR & \multirow{2}{*}{ BB-AA } & $\mathrm{a}$ & -0.287 & 0.27 & -0.039 & 0.380 & -0.007 & 0.366 & -0.028 & 0.184 & 0.091 & 0.103 \\
& & $\mathrm{~d}$ & -0.445 & 0.32 & -0.229 & 0.462 & -0.466 & 0.440 & 0.164 & 0.219 & 0.063 & 0.126 \\
\hline
\end{tabular}

${ }^{\text {a}}$ Favorable allele was defined as the one whose frequence increased in lines IOL and COL relative to line C. The additive contrast (a) is the favorable genotype minus the less favorable genotype, and $d=A B-1 / 2(A A+B B)$.

${ }^{b}$ Epidermal growth factor $(E G F)$ could not be estimated with contrasts because only two genotypes occurred.

'Traits measured include ovulation rate (OR), number of fully formed (FF), live (NBA), stillborn, and mummified pigs. Candidate genes were estrogen receptor (ESR), retinol binding protein (RBP4), prostaglandin endoperoxide-synthase 2 (PTGS2), follicle-stimulating hormone $(F S H \beta)$, and prolactin receptor $(P R L R)$. 
multiple reproductive failures in mice was described (Lim et al., 1997). Oocyte maturation was not complete, and the first polar body was usually not extruded. Also, when wild-type blastocysts were implanted into the uteri of mutant mice, they failed to implant.

Retinol-binding protein 4 was studied as a possible candidate gene affecting litter size because it is involved in embryonic development. Yelich et al. (1997) stated that most embryonic death losses occur between d 10 and 18 of gestation, concurrent with trophoblast elongation and secretion of estrogen by the conceptus. Retinolbinding protein 4 , a major protein produced by the conceptus, may have a role in trophoblast elongation (Harney et al., 1990). It also enhances gene expression of transforming growth factor $\beta$ via retinoic acid receptors (Yelich et al., 1997). Rothschild et al. (2000), using data of 2,500 litters of six commercial lines, reported an additive effect associated with $R B P 4$ of 0.23 pigs/litter.

Allele Frequencies and Effects. The magnitude of the differences in allele frequencies between IOL and $\mathrm{C}$ and between $\mathrm{COL}$ and $\mathrm{C}$ were small (less than 0.06) for markers within the ESR, RBP4, and EGF loci. The differences in allele frequencies were greater for the $F S H \beta, P R L R$, and PTGS2 loci. Within these latter three loci, there was an approximately linear increase in frequency of the favorable allele between the lines that were separated by eight generations of selection (COL and $\mathrm{C}$ ) and the lines separated by 16 generations of selection (IOL and C).

The effects of selection, different frequencies in the founder animals, and random genetic drift could have caused allele frequencies to differ among lines. The base generation was sampled to minimize founder effects. The I and C lines were created from a common base population in which littermates were assigned at random to either the I or $\mathrm{C}$ line. All base generation parents were represented in both lines.

Random genetic drift is a nondirectional force that acts to change allele frequencies. In the absence of selection, the amount of drift depends on allele frequencies and effective population size. The estimated inbreeding coefficients at Generation 16 were used to estimate effective population sizes ( $\mathrm{N}=38$, IOL; $53, \mathrm{COL}$; and 54, C). For alleles with frequencies between 0.1 and 0.5 , these values of $\mathrm{N}$ result in estimates from 0.029 to 0.057 for SE of change in allele frequency within lines in any generation due to drift. After drift begins, it is most probable that an allele's frequency will continue to change in the same direction (Falconer and Mackay, 1996). Thus, drift could have caused the linear increase in frequencies of favorable alleles at the PTGS2, FSH $\beta$, and PRLR loci. Knowledge of base generation allele frequencies is needed to calculate the probability that random drift alone caused the order of favorable allele frequencies to be $\mathrm{C}, \mathrm{COL}$, to IOL at each of these three loci.

The fact that frequencies of favorable alleles at three loci are approximately linearly ordered according to number of generations of selection also fits a selection model. Equations from Falconer and Mackay (1996) for an additive model were used to determine values of the selection coefficient (s) against the homozygous genotypes for the unfavorable alleles at each of the PTGS2, $F S H \beta$, and PRLR loci. Assuming allele frequencies in the control line represent the base generation, values of s that would have produced observed allele frequency changes in line IOL are $0.13,0.25$, and 0.21 for the PTGS2, FSH $\beta$, and PRLR loci, respectively. However, even with selection, allele frequencies at these loci were subject to genetic drift. With selection, the amount of drift depends approximately on the product of effective population size and the selection coefficient at that locus (Hartl and Clark, 1989). For effective population size of $\mathrm{N}$ and selection coefficient of s against the least favorable homozygous genotype, selection has little effect on rate of genetic drift if $\mathrm{Ns}<1$. Thus, selection coefficients greater than 0.025 would have slowed the rate of increase in the frequency of an unfavorable allele in lines IOL and COL and would have speeded the rate of increase of a favorable allele. With drift, selection coefficients less than these calculated values could have produced the same changes in allele frequencies.

The joint effects of selection and drift as forces for change in allele frequencies in this study cannot be separated. When inbreeding coefficients were incorporated into the variances of allele frequency differences among lines, the estimates of standard errors were increased in the range of three to seven times (Table 5). Changes in allele frequencies were not significant, although differences calculated without including drift variance were significant. Thus, a selection model cannot be ruled out as the cause of the linear increase in allele frequencies at the PTGS2, FSH $\beta$, and PRLR loci from lines $\mathrm{C}$ to COL to IOL (Table 3).

When selection lines have accumulated inbreeding of the levels in these lines, changes in frequency for any allele will not be significant, and evaluating changes in gene frequency by itself is not informative. However, allele frequency changes that are consistent with additive and dominance effects give greater evidence that selection caused the changes.

The linear regression of phenotype on genotype, fitting all marker genotypes simultaneously and using an animal model to account for the background genotypes and fixed effects of year and line, yielded no significant estimates of allele substitution effects. At several loci, including the $F S H \beta$ and $P R L R$ loci for which there were linear increases in allele frequencies, the estimate of the effect of the favorable allele was negative. This finding does not support a selection model operating at these loci. In addition, using estimates of allele frequency changes and the a and d effects, we calculated that only 2 to $5 \%$ of the total responses in ovulation rate and litter size could be explained by allele frequency changes at all loci studied.

The additive and dominance effects were estimated both with and without an animal model. Estimates were nearly identical from both analyses. Only one ef- 
fect was found to be significantly different from zero, the dominance effect of PTGS2 on the number of mummies. Standard errors were approximately $10 \%$ greater for effects estimated with an animal model, consistent with the results of the simulation study of Kennedy et al. (1992).

Finding no significant effects for any of the genes on any of the traits was an unexpected result, based on results of other studies. Messer et al. (1996a) reported effects associated with $R B P 4$ to be $0.52 \pm 0.45$ for litter size in hyperprolific Large White sows in France and $0.32 \pm 0.30$ for control sows; Rothschild et al. (2000) reported smaller effects in over 2,000 litters from across several populations. Retinol binding proteins are synthesized just before elongation of the trophoblast (Yelich et al., 1997). This timing of transcription and the role of $R B P 4$ in embryo development implicate it as a candidate gene for litter size. However, it did not seem to explain response to selection in our lines.

The inconsistency across lines of the effects of an allele is evident from the work reported by Vincent et al. (1998). They reported the $P R L R$ marker was linked to a significant additive effect on litter size in three of five PIC lines. Significant dominance effects occurred in two of the three lines for number born alive, but they were opposite in $\operatorname{sign}(\mathrm{d}=-0.33, P<0.1 ; \mathrm{d}=0.63, P<$ 0.01). Significant additive effects also existed in the same two lines for total number born $(P<0.05$; range from $\mathrm{a}=0.16$ to $\mathrm{a}=0.51$ ) and the dominance effect was also important in one line $(P<0.05, \mathrm{~d}=0.55)$. In one line, the additive effect for number born alive was -0.33 , whereas it was positive $(0.47)$ in two other lines. There were more records in the data reported by Vincent et al. (1998) than in the current study. The lines with significant effects mentioned above had from 261 to 416 animals per line, and some sows had multiple records, giving a total of 685 to 1,197 records per line. The variation among lines in that study and the different results in the current study could be due to sampling. Short et al. (1997) stated that over 1,000 records were needed before a stable estimate of 0.42 pigs per litter in firstparity gilts of the additive effect of the $\mathrm{B}$ allele of the $E S R$ gene occurred.

The ESR locus did not explain response to selection in the IOL and COL lines. The gene likely was segregating in the base generation because both the A and $\mathrm{B}$ alleles existed in Line IOL. However, the frequency of the $B$ allele, defined as the favorable allele (Short et al., 1997), was 0.06 after 16 generations of selection. The $\mathrm{B}$ allele was lost due to random drift in line $\mathrm{C}$, presumably before the eighth generation when Line COL was formed because it did not exist in either Lines $\mathrm{C}$ or COL.

The candidate gene analysis of $\mathrm{Li}$ et al. (1998), in which a significant difference of 2.53 pigs per litter for alternative homozygotes for two alleles of $F S H \beta$ was found, used a polymorphism different from the one we studied. The polymorphism we studied may be in less linkage disequilibrium with the causative mutation.
Cassady et al. (2000) found greater concentrations of circulating $\mathrm{FSH}$ in the lines selected for increased ovulation rate than in their randomly selected controls. However, the $F S H \beta$ gene does not seem to explain response to selection in Lines IOL and COL. It is important to stress that the lack of association between a polymorphism within a gene and a phenotype does not mean that the gene product is not important in regulating the trait. Effects of transcriptional and(or) translational events at other loci may combine to regulate FSH levels in these selection lines of pigs. Indeed, a recent QTL scan for FSH levels in pigs identified several chromosomal regions, independent of the $F \mathrm{SH} \beta$ locus, influencing this trait (G. Rohrer, personal communication).

One possible reason for the lack of effect in the current study, by genes that had positive effects on litter size in other studies, is that different linkage disequilibrium existed in the populations. The polymorphism in the genes studied may not directly affect the trait. These polymorphisms could be markers linked with the causative mutation within the gene or a closely linked gene. Different linkage relationships may be the reason estimates of the effects of genes differ across populations.

Background effects of other genes and interactions of these genes with the markers can also cause estimates of gene effects to differ across populations. Little is known about the magnitude of epistatic variation in the traits studied here. But if epistasis exists, the effect of a particular allele depends on its frequency and the frequency of alleles at other loci. Because of epistasis, polymorphisms for one gene could have a small effect in one population, yet explain a significant portion of the variance in another population.

Cassady (1999) found results consistent with those of this study. He performed a complete genome scan for QTL affecting reproduction traits in an $\mathrm{F}_{2}$ population of the Nebraska Index and Control lines that were the foundation lines for those used here. He found evidence $(P<0.05)$ of a QTL on chromosome 11 affecting number of pigs per litter, one QTL on each of chromosomes 5 and 13 affecting number of stillborn pigs per litter, and one QTL on chromosome 9 affecting ovulation rate. The PTGS2 locus, located on chromosome 9, is the only one of the candidate genes that we studied that is located on one of these chromosomes. However, the QTL for ovulation rate found by Cassady (1999) was at approximately the $1 \mathrm{cM}$ position, whereas PTGS2 has been mapped between markers S0295 and S0114, which are at approximately positions 100 and $123 \mathrm{cM}$, respectively, on the USMARC linkage map (Gladney et al., 1999). Thus, results of the QTL genome scan support the conclusion that the candidate genes studied here do not have large effects on ovulation rate or litter size in this population.

\section{Implications}

Six candidate genes for effects on ovulation rate and litter size were studied in lines separated by 8 and 16 
generations of selection. The selection lines exceeded the control line by 20 to $50 \%$ in ovulation rate and litter size at birth. None of the markers studied explained a significant portion of this response. Line differences in frequencies of alleles of these markers were observed. Random genetic drift likely caused these differences, but effects of selection cannot be ruled out. The selection response was likely due to small changes in the frequencies of several genes. Other studies have reported that the candidate genes studied affect litter size. However, direct selection for alleles of these genes may not increase litter size in all populations.

\section{Literature Cited}

Boldman, K. G., L. A. Kriese, L. D. Van Vleck, and S. D. Kachman. 1993. A manual for use of MTDFREML. A set of programs to obtain estimates of variances and covariances [DRAFT]. ARS, USDA, Washington, DC.

Cassady, J. P. 1999. Identification of quantitative trait loci affecting reproduction in pigs. Ph.D. dissertation. University of Nebraska, Lincoln.

Cassady, J. P., R. K. Johnson, and J. J. Ford. 2000. Comparison of plasma FSH concentration in boars and gilts from lines selected for ovulation rate and embryonal survival, and litter size and estimation on (co)variance components for FSH and ovulation rate. J. Anim. Sci. 78:1430-1435.

Falconer, D. S., and T. F. C. Mackay. 1996. Introduction to Quantitative Genetics. 4th ed. Addison Wesley Limited, Edinburg Gate, Harlow Essex, U.K.

Geisert, R. D., M. T. Zavy, R. J. Moffatt, R. M. Blair, and T. Yellin. 1990. Embryonic steroids and the establishment of pregnancy in pigs. J. Reprod. Fertil. Suppl. 40:293-305.

Gladney, C. D., V. G. Martinez, R. K. Brumbaugh, B. J. DeGroot, R. C. Linville, A. M. Oomen, R. M. Huebinger, L. A. Messer, M. F. Allan, and D. Pomp. 1999. Rapid Communication: Mapping of the prostaglandin-endoperoxide synthase 2 (PTGS2) gene to porcine chromosome 9 and bovine chromosome 16 by linkage analysis using novel PCR-RFLP. J. Anim. Sci. 77:787-788.

Hadley, M. E. 1996. Endocrinology. 4th ed. Prentice Hall, Upper Saddle River, NJ.

Hafez, E. S. E. 1993. Reproduction in Farm Animals. 6th ed. Lea and Febiger, Malvern, PA.

Harney, J. P., M. A. Mirando, L. C. Smith, and F. W. Bazer. 1990. Retinol-binding protein: A major secretory product of the pig conceptus. Biol. Reprod. 42:523-532.

Hartl, D. L., and A. G. Clark. 1989. Principles of Population Genetics. 2nd ed. Sinauer Associates, Sunderland, MA.

Johnson, R. K., M. K. Nielsen, and D. S. Casey. 1999. Responses in ovulation rate, embryonal survival, and litter traits in swine to 14 generations of selection to increase litter size. J. Anim. Sci. 77:541-557.

Kennedy, B. L., M. Quniton, and J. A. M. van Arendonk. 1992. Estimation of effects of single genes on quantitative traits. J. Anim. Sci. 70:2000-2012.

Li, N., Y. F. Zhoa, L. Xiao, F. J. Zang, Y. Z. Chen, R. J. Dai, J. S. Zang, S. Q. Shen, Y. F. Chen, and C.X. Wu. 1998. Candidate gene analysis for identification of genetic loci controlling litter size in swine. In: Proc. 6th World Cong. Genet. Appl. Livest. Prod., Armidale, Australia. pp 183-186.

Lim, H., B. C. Paria, S. K. Das, J. E. Dinchuk, R. Langenbach, J. M. Traskos, and S. K. Dey. 1997. Multiple female reproductive failures in cyclooxygenase 2-deficient mice. Cell 91:197-208.
Mannaertz, B., J. Uilenbrock, P. Schot, and R. de Leeuw. 1994. Folliculogenesis in hypophesectomized rats after treatment with recombinant human follicle stimulating hormone. Biol. Reprod. $51: 1,72-81$.

Mendez, E. A., L. A. Messer, N. J. Larsen, A. Robic, and M. F. Rothschild. 1999. Rapid communication: Epidermal growth factor maps to pig chromosome 8. J. Anim. Sci. 77:494-495.

Messer, L. A., L. Wang, C. Legualt, and M. F. Rothschild. 1996a. Mapping and investigation of candidate genes for litter size in French large white pigs. Anim. Genet. 27 (Suppl. 2):101-119.

Messer, L. A., L. Wang, J. Yelich, D. Pomp, R. D. Geisert, and M. F. Rothschild. 1996b. Linkage mapping of the retinol binding protein 4 (RBP4) gene to porcine chromosome 14. Mamm. Genome 7:396.

Ollivier, L., L. A. Messer, M. F. Rothschild, and C. Legault. 1997. The use of selection experiments for detecting quantitative trait loci. Genet. Res. 69:227-232.

Rothschild, M. F. 1996. Genetics and reproduction in the pig. Anim. Reprod. Sci. 42:143-151.

Rothschild, M. F., C. Jacobson, D. A. Vaske, C. Tuggle, L. Wang, T. Short, G. Eckardt, S. Sasaki, A. Vincent, D. G. McLaren, O. Southwood, H. van der Steen, A. Mileham, and G. Plastow. 1996. The estrogen receptor locus is associated with a major gene influencing litter size in pigs. Proc. Natl. Acad. Sci. USA 93:201-205.

Rothschild, M. F., L. A. Messer, A. Day, R. Wahs, T. Short, O. Southwood, and G. Plastow. 2000. Investigation of the retinol binding protein (RBP4) gene as a candidate gene for litter size in the pig. Mamm. Genome 11:75-77.

Rothschild, M. F., and M. Soller. 1997. Candidate gene analysis to detect traits of economic importance in domestic livestock. Probe 8:13-22.

Ruiz-Flores, A, J. P. Cassady, and R. K. Johnson. 1999. Responses in ovulation rate and litter size to two-stage selection in swine. J. Anim. Sci. 77(Suppl. 1):143(Abstr.).

Short, T. H., M. F. Rothschild, O. I. Southwood, D. G. McLaren, A. de Vries, H. van der Steen, G. R. Eckardt, C. K. Tuggle, J. Helm, D. A. Vaske, A. J. Mileham, and G. S. Plastow. 1997. Effect of the estrogen receptor locus on reproduction and production traits in four commercial pig lines. J. Anim. Sci. 75:3138-3142.

Vincent, A. L., G. Evans, T. H. Short, O. I. Southwood, G. S. Plastow, C. K. Tuggle, and M. F. Rothschild. 1998. The prolactin receptor gene is associated with increased litter size in pigs. In: Proc. 6th World Cong. Genet. Appl. Livest. Prod., Armidale, Australia. pp 15-18.

Wang, X. N., and G. S. Greenwald. 1993a. Hypophysectomy of the cyclic mouse. I. Effects on folliculogenesis, oocyte growth, and follicle stimulating hormone and human chorionic gonadotropin receptors. Biol. Reprod. 48:585-594.

Wang, X. N., and G. S. Greenwald. 1993b. Hypophysectomy of the cyclic mouse. II. Effects of follicle stimulating hormone (FSH) and leuteinizing hormone on folliculogenesis, FSH and human chorionic gonadotropin receptors and steroidogenesis. Biol. Reprod. 48:595-605.

Weir, B. S. 1996. Genetic Data Analysis II. 2nd ed. Sinauer and Associates, Sunderland, MA.

Yangfan, Li, J. R. Molina, J. Klindt, D. J. Bolt, and L. L. Anderson. 1989. Prolactin maintains relaxin and progesterone secretion by aging corpora lutea after hypophysial stalk transection or hypophysectomy in the pig. Endocrinology 124:1243-1294.

Yelich, J., D. Pomp, and R. Geisert. 1997. Detection of transcripts for retinoic acid receptors, retinal-binding protein, and transforming growth factors during rapid trophoblastic elongation in the porcine conceptus. Biol. Reprod. 57:286-294. 